surgery than for urology. This is evidently due to the larger number of suprapubic and unclassified operations in general surgery, which have a higher fatality rate. But for the operations classified as retropubic and transurethral resction the fatality rates are virtually that an important proportion of the large number of prostatectomies in general surgical departments categorised as "not elsewhere classified" may have been retropubic or so, the fatality rate for these two operations would be higher than the rate shown for general surgery.

The comparison in table I takes no account of differences in age and type of admission between the two specialties. Ashley and his colleagues $^{3}$ showed that an important factor in accounting for the higher overall fatality in hyperplasia of prostate admissions and subsequent prostatectomy in regional hospital board hospitals than in hospitals under boards of governors was the higher proportion of unplanned admissions to the regional board hospitals. In addition to being presumably more seriously ill than the patients with planned admissions, unplanned admission patients tended to be older and less fit. Table II shows for hyperplasia of the prostate, for the two three-year periods 1971-73 and 1974-76, the difference between departments of urology and general surgery in the percentages of patients over the age of 75 and of emergency admissions, as well as the fatality rates in these types of admission. There is a much higher proportion of emergency admissions to genera surgical departments and these cases carry a higher fatality rate that that for all admissions. The over-75 patients also have a relatively high hospital fatality rate and there are proportionately slightly more of them admitted to general surgical departments. These two factors probably account for the higher fatality rate for all admissions to general surgery (a difference which reaches statistical significance for the six years combined).

It is interesting that there is no significant difference in either specialty between the Scottish hospital fatality rates for hyperplasia of the prostate discharges and those for prostatectomy discharges. In the series of Ashley and his colleagues the fatality rate for the same as for urology. It is, however, possible transurethral resection operations. If this were

teaching and regional hospital board hospital together was $4.3 \%$ for all admissions for hyperplasia, but only $1.6 \%$ for prostatectomy Presumably much of this difference was due to deaths in patients not operated on either because they were too ill or for other reasons. This difference between Scotland and London may be accounted for by the fact that, while the Scottish fatality rate for emergency admissions for hyperplasia was 3\% (including both operated and unoperated cases), the equivalen figures for the London series was over $9 \%$.

Information Services Division,

J M G WILSON

Cottish Health Service

Edinburgh EH5 3SQ

1 Graham AG. Br $\mathcal{F}$ Urol 1977;49:679-82. Scottish Home and Health Department. Scottish
hospital in-patient statistics. Edinburgh: HMSO (annual publication)

${ }^{3}$ Ashley JSA, Howlett A, Morris JN. Lancet 1971 ;ii: 1308-11.

SIR,-Mr P F Boreham's point (15 March, p 789) is well made. Urology and general surgery have shared the same bed for a long time and will continue to do so for many years to come. In this respect urologists are more than proud of their associate members in the British Association of Urological Surgeons.

Rather than encourage division among those who practise urology in this country, surely we should now seek to strengthen the association to our mutual benefit and, perhaps more importantly, to that of our patients. It would seem therefore important no longer to discuss "an interest" or even "experience" in urology, but now to describe a surgeon with training in urology. In this respect it is important to note that the Royal College of Surgeons has clearly laid down that for appointments requiring both surgical and urological responsibility the training requirements for the applicant should consist of at least two years at senior registrar level in urology. It should be remembered that a urologist is not only an expert at transurethral prostatectomy, but through the development of his subject has increasing contributions to make in the management of urological cancer, stone disease, urinary infection, and paediatric

TABLE I-Prostatectomy, Scotland, Hospital fatality by department and operation, 1971-76

\begin{tabular}{|c|c|c|c|c|c|c|c|}
\hline \multirow[b]{2}{*}{ Operation } & \multicolumn{4}{|c|}{ Urology } & \multicolumn{3}{|c|}{ General surgery } \\
\hline & & $\begin{array}{l}\text { Discharges } \\
\text { and deaths } \\
(D+D)\end{array}$ & Deaths & $\begin{array}{c}\text { Percentage } \\
\text { deaths/ } \\
D+D\end{array}$ & $\begin{array}{c}\text { Discharges } \\
\text { and deaths } \\
(\mathrm{D}+\mathrm{D})\end{array}$ & Deaths & $\begin{array}{c}\text { Percentage } \\
\text { deaths } / \\
\mathrm{D}+\mathrm{D}\end{array}$ \\
\hline $\begin{array}{l}\text { Suprapubic transvesical } \\
\text { Retropubic .. } \quad . \\
\text { Transurethral } \\
\text { Not elsewhere classified } \\
\text { All operations }\end{array}$ & $\begin{array}{l}\ldots \\
\because \\
\cdots\end{array}$ & $\begin{array}{r}1956 \\
1875 \\
6116 \\
289 \\
10236\end{array}$ & $\begin{array}{r}72 \\
34 \\
96 \\
11 \\
213\end{array}$ & $\begin{array}{l}3 \cdot 7 \\
1.8 \\
1.6 \\
3.8 \\
2.1\end{array}$ & $\begin{array}{l}2954 \\
1198 \\
1641 \\
2379 \\
8172\end{array}$ & $\begin{array}{r}91 \\
19 \\
30 \\
79 \\
219\end{array}$ & $\begin{array}{l}3 \cdot 1 \\
1 \cdot 6 \\
1 \cdot 8 \\
3 \cdot 3 \\
2 \cdot 7\end{array}$ \\
\hline
\end{tabular}

TABLE II-Hyperplasia of prostate: percentage discharges and deaths over age 75 and percentage emergency admissions with fatality percentage-Scotland $1971-73$ and $1974-76^{2}$

\begin{tabular}{|c|c|c|c|c|c|c|c|c|}
\hline & \multicolumn{4}{|c|}{ Urology } & \multicolumn{4}{|c|}{ General surgery } \\
\hline & \multicolumn{2}{|c|}{$1971-1973$} & \multicolumn{2}{|c|}{ 1974-1976 } & \multicolumn{2}{|c|}{ 1971-1973 } & \multicolumn{2}{|c|}{ 1974-1976 } \\
\hline & No & $\%$ & No & $\%$ & No & $\%$ & No & $\%$ \\
\hline $\begin{array}{l}\text { Percentage discharges over } 75 \\
\text { Fatality rate over } 75 \ldots \\
\text { Percentage emergency admissions } \ldots \\
\text { Fatality rate for emergency admissions } \\
\text { Fatality rate for all admissions }\end{array}$ & $\begin{array}{r}1612 \\
70 \\
1553 \\
52 \\
128 / \\
6058\end{array}$ & $\begin{array}{r}26 \cdot 6 \\
4.3 \\
25.6 \\
3.3 \\
2.1\end{array}$ & $\begin{array}{r}1955 \\
70 \\
1662 \\
49 \\
130 / \\
6849\end{array}$ & $\begin{array}{r}28.5 \\
3.6 \\
24.3 \\
2.9 \\
1.9\end{array}$ & $\begin{array}{r}1699 \\
71 \\
2511 \\
108 \\
164 / \\
5768\end{array}$ & $\begin{array}{r}29.4 \\
4.2 \\
43.5 \\
4.3 \\
2.8\end{array}$ & $\begin{array}{r}1560 \\
98 \\
2306 \\
69 \\
119 / \\
5256\end{array}$ & $\begin{array}{r}29 \cdot 7 \\
6 \cdot 3 \\
43 \cdot 9 \\
3 \cdot 0\end{array}$ \\
\hline
\end{tabular}

urology, and in certain centres renal failure, dialysis, and transplantation. By all means let us continue to encourage surgeons to take an interest in urology but not to practise that urology until they have been properly trained in the specialty to the level required by the College of Surgeons. In this way it should be perfectly possible for senior registrars to take on appointments which carry both surgical and urological commitments in a manner of mutual inclusivity.

Patrick SMith

Bristol Royal Infirmary, Bristol BS2 8HW

SIR,-Many years ago I spent a week in Newcastle upon Tyne watching the work of Wardill, then recognised as the leading authority in Britain on transurethral prostatectomy. Apart from this, however, he had also made some mark by devising a new operation for cleft palate. How many prostatectomists would care to take on a cleft palate today? But then, of course, Wardill was a general surgeon.

Any experienced general surgeon has only to see any operation done a few times to be able to master its technique-in whatever specialty. The why and when might take a little longer. The provincial general surgeons in the 'twenties and 'thirties did not give up removing tonsils, doing hysterectomies, and reducing fractures of the femur because they found them too difficult. They gave them up because the lessening fear of the public to come into hospital at all was making the volume of work impossible to deal with. They therefore handed these over to a younger generation to develop specialties in the provincial hospitals which scarcely existed outside the teaching schools before the 'thirties.

I do not mind the transurethral prostatectomists building their own little empire, but surely they should not do this by denigrating the abilities of the general surgeon. After all, it was a general surgeon in Newcastle who, nearly 40 years ago, showed them how to do it.

Burton-upon-Trent, Staffs

ROBERT BEWICK

${ }^{*}{ }^{*}$ This correspondence is now closed.-ED, BMY.

Non-fatal disease due to inhalation of nebulised paraquat

SIR,-Drs $M$ George and $\mathbf{R} B$ HedworthWhitty's article (29 March, p 902) prompts me to report another case of disease apparently due to inhalation of nebulised paraquat.

My patient was born in 1930 and was under my care for follow-up of pulmonary tuberculosis, which had been treated in the 1960 s and which remains quiescent. During 1974 he experienced a total of seven episodes of malaise, cough, fever, and sputum. He himself finally discovered the cause of these and he and his wife noticed that they all followed 36-48 hours after he had been working in a local stone quarry. $\mathrm{He}$ was then working using a diamond stone-cutting saw which required to be water cooled. Not having water near the saw he carried it in a plastic container from a nearby tap. He later discovered that the container had been dumped over the side of the quarry and had previously contained Gramoxone (paraquat). It seems therefore that the water used to lubricate the wheel was contaminated and when the wheel was cutting a fine spray of water was 
blown into his face. After he replaced the original Gramoxone container with a new plastic containe he had no further symptoms. His chest $x$-radiograph during these episones of fever was not significantly altered.

As in the case reported by Drs George and Hedworth-Whitty, it was not possible to investigate this further as my patient was not seen soon after exposure; but his story strongly suggests that inhalation of paraquat was responsible for his symptoms.

R J ADAM

Horton General Hospital,
Banbury, Oxon OX16 9AZ

\section{Ectopic production of methionine enkephalin and beta-endorphin}

SIR,-In the paper by Dr P T Pullan and others (15 March, p 758) three met-enkephalinand $\beta$-endorphin-producing tumours, recognised histologically as carcinoids, are nevertheless described as non-endocrine. This view is surely insupportable.

In terms of their admittedly not invariable production of amines carcinoids have been regarded as endocrine for over a quarter of a century and in most parts of the world they are now recognised as apudomas, and therefore as "neuroendocrine," derived from cells which are "endocrinologically totipotent with respect to both amines and peptides."2 They can thus be defined as endocrine or neuroendocrine tumours capable of producing "any of the 35 APUD peptides, or variations of the correct sequences of any of the known or presently unknown prohormones and preprohormones, or fragments thereof."3

Beta-endorphin and met-enkephalin are integral parts of pro-opiocortin, the adrenocorticotrophic hormone-lipotropin precursor. Their postulated production by small-cell carcinoma of the lung, another apudoma, is virtually certain ${ }^{5}$ and the secretion of $\beta$ endorphin by yet another apudoma (islet-cell tumour) is hardly surprising. Only in the sense originally used by Liddle $e t a l^{6}$ is this function ectopic-an interpretation opposed by Rees and Ratcliffe, ${ }^{7}$ who maintained that a hormone is ectopic only when its normal sites of synthesis are known (which they are not). I consider that it is misleading and wrong to interpret the three tumours as non-endocrine and that current use of the word ectopic should be qualified by a note in the text of any paper in which it is used.

I have no quarrel with the proposition that ectopic peptides secreted by endocrine tumours, even if they are not called apudomas, may be responsible for much otherwise inexplicable symptomatology.

\section{Royal Postgraduate Medica
School, \\ th Hospital, \\ London $\mathrm{W}_{12} \mathrm{OHS}$}

1 Pearse AGE, Polak JM, Heath CM. Virchow

2 Pearse AGE. Zkrebsforsch 1975;84:1-18.

2 Pearse AGE. Clin Endocrinol Metab (in press).

- Eipper BA, Mains RE. $₹$ Biol Chem 1978;253:5732-44

Bertagna XY, Nicholson WE, Sorenson GD
Pettengill OS, Mount CD, Orth DN. Proc Nat Pettengill OS, Mount CD, Or
Acad Sci USA 1978;75:5160-4.

- Liddle GW, Nicholson WE, Island DP, Orth DN, Abe K, Lowder SC. Rec Prog Horm Res 1969;25:

' Rees LH, Ratcliffe JG. Clin Endocrinol 1974;3:263-99.

SIR,-I read with interest the paper by Dr P T Pullan and others (15 March, p 758) reporting the presence of methionine enke- phalin and beta-endorphin in carcinoid tumours in three patients with the ectopicadrenocorticotrophin syndrome, and I noted your interesting leading article ( $p$ 741) on this topic. All three patients had affective disorders-one mania and two depression-and these resolved when the tumours were removed. I have recently published ${ }^{1}$ a psychiatric study of 29 patients with Cushing's syndrome ${ }^{1}$ : one of my conclusions was that since the depressive symptoms were relieved by removal of the adrenal glands and were not related to the concentration of plasma cortisol we needed to consider whether "an as yet unknown substance produced by the adrenals is responsible for the depression of Cushing's syndrome." Could it be that opioid peptides are responsible? Might it even be possible that the very rapid remission of psychiatric symptoms after operation was the result of removal of the adrenal medulla rather than the cortex, since enkephalin is normally found in the medulla as Dr Pullan and others state?

A second finding which I reported was that patients whose Cushing's syndrome was the result of an adrenal tumour were considerably less likely to be psychiatrically disturbed than patients with pituitary-dependent Cushing's syndrome, and, indeed, there was a three-infour chance that a patient who was absolutely free from psychiatric symptoms might have tumour: of four patients without psychiatric symptoms, three had a tumour and one had hyperplasia, whereas of 25 patients with psychiatric symptoms, five had a tumour and 20 hyperplasia $\left(\chi^{2}=5.22 ; n=1 ; 0.025>p>\right.$ 0.02 ). It would be interesting to compare observations on the opioid peptides in patients with Cushing's syndrome with and without affective disorders.

Finally, I should like to emphasise that if further work is undertaken in this field it is of the utmost importance that an appropriate description of the patient's psychiatric features should accompany the other clinical details.

The London Hospital,

SAMuel I COHEN

London E1 $1 \mathrm{BB}$

${ }^{1}$ Cohen SI. Br $\mathcal{F}$ Psychiatry 1980;136:120-4.

\section{Is severe restriction of food really a very-high-fat diet?}

SIR,-Your inquirer (Any Questions? 1 March, p 628) correctly states that "severe restriction of food intake in obesity effectively puts the patient on a very high-fat diet," and asks if the harmful effects said to follow a very high-fat diet in Europeans have been observed. Your expert missed the point of this intelligent question-namely, that severe restriction of food intake in obesity causes body fat to be mobilised for energy, in effect a very high-fat diet.

The fat that is mobilised will alter in composition according to the previous diet. For instance, Edinburgh men aged 40 years had in their adipose tissue $7 \cdot 3 \%$ linoleic acid (an essential fatty acid, EFA) and a polyunsaturated: saturated fat $(P: S)$ ratio of 0.30 ; comparable men in Stockholm, who have only about a third of the incidence of coronary heart disease, had $11.8 \%$ linoleic acid and a P:S ratio of $0 \cdot 44 .^{1}$ I normally eat considerable amounts of linoleic acid daily, and my adipose tissue has about $29 \%$ of this EFA, with a $P: S$ ratio of $1 \cdot 3$. In the Finnish hospital study $^{2}$ dietary alteration to increase linoleic acid while keeping total dietary fat constant increased the percentage of this in adipose tissue so that the experimental hospital had $26.9 \%$ of this near. the end of the first period and the control $10.2 \%$; when the hospitals were reversed the experimental one now had $32.5 \%$ linoleic acid and the control 9.8 . The change in diet decreased thrombotic tendency of blood.

So for most people in this country severe restriction of food intake will cause fat to be mobilised that is relatively saturated and very low in EFA. Acute starvation usually produces a slight rise in plasma cholesterol whereas partial starvation usually produces a slight fall. When three epileptics were acutely starved for 11 days this therapy was not successful: one died after a rise in plasma cholesterol of about $90 \% \cdot^{3}$ At the end of the second world war Swiss investigators noted frequent venous thrombosis with occasional pulmonary infarction in undernutrition, 4 and extensive investigations by French investigators found frequent venous thrombi at necropsy, some associated with atheroma ${ }^{5}$; indeed, they emphasised that atheroma occurred at a much earlier age than usual. However, in more severe starvation in the siege of Leningrad and, as so brilliantly studied in tragic circumstances, in the Warsaw ghetto atheroma was conspicuously absent at necropsy. Stress, like severe restriction of food, mobilises fatty acids from adipose tissue. Stressed Americans have increases in catecholamines and in plasma cholesterol, and shortened clotting time.

Severe restriction of food in ordinary persons in this country may therefore be similar to a very high-fat diet in increasing the amount of saturated fatty acids in blood. In a reducing diet fat must be kept low (as your expert states) but it should be relatively rich in EFA. More important, however, is to increase the ratio of EFA to non-EFA by dietary means ${ }^{8}$ in the ordinary diet, and then adipose tissue will be relatively rich in the former.

\section{International Institute of Human}

Hugh Sinclair

Nutrition,

Sutton Courtenay, Oxon OX14 4AW

1 Logan RL, Riemersma RA, Thomson M, et al. Lancet $1978 ; \mathrm{i}: 949-56$

Turpeinen $\mathrm{O}$, Karvonen MJ, Pekkarinen M, et al. Internat f Epidemiol 1979;8:99-118.

Lennox WG, O'Connor M, Bellinger M. Arch - Unternal Med 1926;38:553-65.

et al, eds. Hungerkrankheit, Hungerödem Hungertuberkulose. Basel: Benno Schwalbe, 1948:181-246. Lamy M, Lamotte M, Lamotte-Barrillon S. La dénutrition, clinique-biologie-therapeutique. Paris: Doin, 1948.

- Apfelbaum E. Maladie de famine. Recherches cliniques sur la famine exécutées dans le Ghetto de Varsovie en 1942.

7 Friedr riedman

Sinclair HM. Lancet 1980;i :414-5.

***Our expert writes: "Dr Sinclair correctly points to the abrupt changes brought about by starvation, the hazards of which are well recognised. During fasting adipose tissue is mobilised to glycerol and fatty acids and the concentration of free fatty acids in the blood is increased. ${ }^{1}$ Sometimes during total starvation excessive mobilisation of fatty acids may result in the deposition of triglycerides in the liver producing a fatty liver. Reduction of weight, however, regularly causes a fall in serum cholesterol and serum triglyceride concentrations. ${ }^{2}$ Moreover, the improvement sometimes persists when a normal-calorie diet is resumed, suggesting that plasma lipoprotein metabolism is influenced not only by the calorie balance but by the total adipose tissue mass. Even in hyper-beta-lipoproteinaemia cholesterol levels may fall during fasting. ${ }^{3}$ In this famous Framingham study the serum cholesterol was shown to have a linear correlation with weight change. The 